\section{Effects of Nonwoven Polypropylene Covering during Overwintering on Growth and Bulb Yield of Intermediate-day Onion}

\author{
Jongtae Lee ${ }^{1}$, Byeonggyu Min, Heedae Kim, and Juyeon Kim \\ Onion Research Institute, Gyeongsangnam-do Agricultural Research and \\ Extension Services, Changnyeong 50319, Republic of Korea
}

\section{Young-Seok Kwon \\ Department of Vegetable, National Institute of Horticultural and Herbal Science, Wanju 55365, Republic of Korea}

\author{
George E. Boyhan \\ Department of Horticulture, University of Georgia, 1111 Miller Plant \\ Science Building, Athens, GA 30602-7273
}

Additional index words. bolting, doubles, weather, soil temperature, soil moisture potential

\begin{abstract}
This study evaluated the effects of a nonwoven polypropylene (NPP) covering during overwintering with different mulch types and transplant times on bulb onion growth and yield of intermediate-day onions (Allium cepa $\mathbf{L}$.) during the 2015/2016 and 2016/2017 growing seasons. Field experiments were conducted using a split-split plot design with three replicates. Treatments included main plots containing different mulch types (transparent plastic mulch, black plastic mulch, or bare ground), subplots with different transplanting times (20 Oct., 5 Nov., and 20 Nov.), and sub-subplots containing two onion cultivars (Sunpower and Katamaru). NPP was used to cover all plots on 1 Dec., and it was removed on 28 Feb. Mean daily air temperatures during transplanting and root establishment were $2.6{ }^{\circ} \mathrm{C}$ higher during the $2015 / 2016$ growing season compared with the $2016 / 2017$ season. NPP covering on bare ground increased soil temperature by $2.1{ }^{\circ} \mathrm{C}$ compared with no treatment. Soil water potential with transparent and black mulches and NPP continued to be more than $-10 \mathrm{kPa}$ until early March. Number of leaves, and root and leaf weight were significantly greater during the 2015/2016 growing season than during the 2016/2017 growing season; there were also significantly greater for onion plants grown with transparent plastic mulch than for those grown with black plastic mulch or no mulch on $4 \mathrm{Apr}$. and 5 May. Marketable bulb yield was lower during 2015/2016 $\left(32.0 \mathrm{Mg} \cdot \mathrm{ha}^{-1}\right)$ than during 2016/2017 (38.5 $\mathrm{Mg} \cdot \mathrm{ha}^{-1}$ ); this was due to the increased unmarketable bulb yield, with 33.2 Mg.ha ${ }^{-1}$ bolters and 3.9 Mg.ha ${ }^{-1}$ doubled bulbs during 2015/2016 compared with 3.9

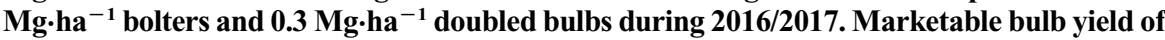
'Katamaru' (38.9 Mg.ha ${ }^{-1}$ ) was greater than that of 'Sunpower' (31.6 Mg.ha ${ }^{-1}$ ). Marketable bulb yield increased with later transplanting times, and onions grown with black plastic mulch achieved the highest bulb yield $\left(43.0 \mathrm{Mg} \cdot \mathrm{ha}^{-1}\right)$, followed by transparent mulch $(34.7$

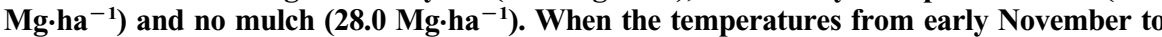
early December were similar to the 30-year average temperatures, marketable bulb yield could increase with the NPP covering, especially for onions grown with black plastic mulch or no mulch when transplanted from late October to early November.
\end{abstract}

Bulb onion is one of the most consumed vegetable in South Korea (Statistics Korea, 2018). In recent years, the overall onion-

Received for publication 25 Oct. 2018. Accepted for publication 12 Dec. 2018.

The research was performed with the support of the Cooperative Research Program for Agriculture Science \& Technology Development (Project title: Effect of nonwoven polypropylene fabric covering during overwintering for sustainable bulb onion production, Project No. PJ01176501) from the Korean Rural Development Administration, Republic of Korea.

${ }^{1}$ Corresponding author. E-mail: organicjt@hotmail. com. sprays, and abundant manure compost and chemical fertilizer application. However, the bulb yield has been unstable every year since 2006: it was $74.2 \mathrm{Mg} \cdot \mathrm{ha}^{-1}$ at its highest in 2009, and $57.0 \mathrm{Mg} \cdot \mathrm{ha}^{-1}$ at its lowest in 2012 . Because there were no visible changes in the onion production system during the past decade, the main cause was likely environmental conditions.

The main cultivars of bulb onion in Korea are intermediate day, which are an overwintering type. They are sown in early to mid September, transplanted in late October or early November, undergo root establishment until early December, are overwintered, begin growing again in early February, reach their maximum vegetative stage and begin bulb development in mid to late April, start falling over in mid to late May, and are finally harvested in early to mid June (Lee, 2015). Because onion plants grow in the field for more than 9 months, various abnormal environmental conditions can affect onion growth. During sowing and seedling growth, a typhoon or heavy rain could inundate seed beds, resulting in excessive soil moisture and poor root systems. In addition, high temperatures could cause poor seed germination or infestation of soil-borne diseases, including damping-off, because of frequent irrigation. In mid October to early November, heavy rain could delay field preparation and transplanting work, subsequently causing poor root establishment. Delayed transplanting is one of the main causes of stand reduction because of winter frost injury. High temperatures during root establishment could cause doubling or bolting, whereas low temperatures could result in poor root establishment, growth retardation, or frost injury. Heavy or frequent rain could cause poor root development, cause disease infestation during the vegetative growth and bulb development stages, and delay bulb harvest, whereas high temperatures or drought during the bulb development stage could cause incomplete bulb formation, resulting in decreased marketable bulb yield.

Onion bulb yield variability has been largely explained by both short-term extreme precipitation and temperature variability (drought-heat stress) for long-day onions in the Czech Republic (Potopova et al., 2016). Kalbarczyk (2010) reported that long-day onion bulb yield was favored by the following: above-average sunshine duration $(8.1 \mathrm{~h})$ and above-average air temperature $\left(13.0^{\circ} \mathrm{C}\right)$ from sowing to the end of emergence; average sunshine duration $(7.4 \mathrm{~h})$, average soil temperature $\left(18.7^{\circ} \mathrm{C}\right)$, average air temperature $\left(16.8{ }^{\circ} \mathrm{C}\right)$, and above-average rainfall $(2.8 \mathrm{~mm})$ from emergence to the beginning of the falling over of the leaves; and belowaverage soil temperature $\left(17.3^{\circ} \mathrm{C}\right)$ and air temperature $\left(16.0^{\circ} \mathrm{C}\right)$ from the beginning of the falling over of the leaves to harvest.

Climate change and global warming are major issues worldwide. Jung et al. (2002) reported that temperatures showed an upward trend at a rate of $0.23{ }^{\circ} \mathrm{C} /$ decade from 1954 to 1999 , and that climatic extremes have 
increased during recent decades in South Korea. In a more recent study, the results of Min et al. (2015) showed an upward trend in temperature at a rate of $0.23{ }^{\circ} \mathrm{C} /$ decade from 1960 to 2012; this warming trend occurred faster in the winter than in the summer, but recent ice melting in the Arctic Sea and associated warming have brought cold snaps to East Asia during the winter. In addition, Min et al. (2015) indicated that the increased frequency and intensity of precipitation in summer and decreased frequency of precipitation in spring and winter implied greater risks of flood and drought, respectively. This trend was attributed to the intensification of typhoon activity in the vicinity of the Korean peninsula, possibly induced by global warming.

In recent years, heavy or frequent rain affected by autumn typhoons and low air temperatures during early winter, especially in southeastern Korea, frequently delayed bed preparation and the transplanting of onion seedlings, resulting in increased stand reduction and decreased bulb yield. For example, according to the annual reports of the Korea Meteorological Administration (KMA, 2018), rainfall at the Hapcheon weather station from late Oct. to mid Nov. in 2011 was $191.3 \mathrm{~mm}$ compared with $33.8 \mathrm{~mm}$ according to the 30 -year average, and the mean daily air temperature from mid Dec. 2011 to early Jan. 2012 was $-2.5{ }^{\circ} \mathrm{C}$ compared with $0.6{ }^{\circ} \mathrm{C}$ according to the 30 year average. The mean daily air temperature from late Nov. 2012 to early Jan. 2013 was $-0.7{ }^{\circ} \mathrm{C}$, which was $2.76^{\circ} \mathrm{C}$ lower than that of a 30 -year average. Rainfall from mid Oct. to late Oct. 2014 was $114.5 \mathrm{~mm}$, which was $90.2 \mathrm{~mm}$ more than the 30 -year average. In contrast, the mean daily air temperature from early Nov. to late Dec. 2015 was $6.9{ }^{\circ} \mathrm{C}$ compared with the average of $4.5^{\circ} \mathrm{C}$; during the same month of the year, rainfall was $130.7 \mathrm{~mm}$ compared with $43.3 \mathrm{~mm}$ according to the 30 -year average.

Therefore, the aim of this study was to evaluate the effects of using nonwoven polypropylene (NPP) covering during overwintering with different mulch types and transplanting times on soil temperature and moisture potential as well as bulb onion growth and bulb yield characteristics.

\section{Materials and Methods}

Field experiment. The field experiment was conducted at the experimental field of the Onion Research Institute located in Changnyeong county (lat. $35^{\circ} 56^{\prime} 45^{\prime \prime} \mathrm{N}$, long. $\left.128^{\circ} 48^{\prime} 60^{\prime \prime} \mathrm{E}\right)$, Republic of Korea, during the $2015 / 2016$ and $2016 / 2017$ growing seasons. The soil types were silt loam in surface soil and silty clay loam in subsoil. Onion seeds were sown directly into beds that were $1.0 \mathrm{~m}$ wide and $0.2 \mathrm{~m}$ high on 5 Sept. 2015 and 5 Sept. 2016. Onion bulbs were harvested on 7 June 2016 and 7 June 2017.

Experimental plots were prepared $10 \mathrm{~d}$ before transplanting seedlings. Cattle manure compost $\left(20 \mathrm{Mg} \cdot \mathrm{ha}^{-1}\right)$ and preplant fertilizers $\left(80 \mathrm{~kg} \cdot \mathrm{ha}^{-1}\right.$ of $\mathrm{N}$ as urea, $33.6 \mathrm{~kg} \cdot \mathrm{ha}^{-1}$ of $\mathrm{P}$ as fused phosphate, and $58 \mathrm{~kg} \cdot \mathrm{ha}^{-1}$ of $\mathrm{K}$ as potassium sulfate) were applied to the prebedded area according to the fertilizer recommendations of the Rural Development Administration (RDA, 2010). The land was then covered with pesticides containing terbufos (Counta, FarmHangnong, Seoul, South Korea) and fosthiazate (Seonchungtan, FarmHangnong) to reduce the possibility of maggot and nematode attacks. The land was bedded on $1.50 \mathrm{~m}$ center-to-center between adjacent beds with a bed width of $1.00 \mathrm{~m}$ and a height of $0.20 \mathrm{~m}$. Plastic mulch was applied after spraying herbicides containing $43.7 \%$ alachlor (Lasso, FarmHangnong) and $31.7 \%$ pendimethalin (Stomp, FarmHangnong). Each bed was planted with six rows of transplants with spacing of $0.12 \mathrm{~m}$ in rows and $0.18 \mathrm{~m}$ between rows, resulting in a plant density of 33.3 individuals $/ \mathrm{m}^{2}$. Plants were irrigated once with flooding at the time of transplanting but were not irrigated during the entire growing season.

All onion beds were side-dressed twice during early March and late March with 80 $\mathrm{kg} \cdot \mathrm{ha}^{-1}$ of $\mathrm{N}$ as urea and $48 \mathrm{~kg} \cdot \mathrm{ha}^{-1}$ of $\mathrm{K}$ as potassium sulfate. Side-dressing was performed by hand irrespective of the mulch treatment a few days before rain was forecasted. Onions received three application of fungicides with copper oxychloride $(35 \%$ as $\mathrm{Cu})$. metalaxyl-M $(7.5 \%)$ (Ridomil GoldPlus, Kyungnong Co., Seoul, South Korea) to inhibit downy mildew [Peronospora destructor (Berk.) Caspary] and Stemphylium leaf blight [Stemphylium vesicarium (Wall.) Simmons] disease during early and mid March as well as during mid April. They were weeded three times by hand in March, April, and May.

Experimental design. Field experiments were conducted during two consequent seasons using a split-split plot design with three replicates. The main plots included a sheet of transparent mulch, black polyethylene mulch, or bare ground (no mulch). The subplots had transplanting times of 20 Oct., 5 Nov., and 20 Nov. The sub-subplots included two onion cultivars, 'Sunpower' (an $\mathrm{F}_{1}$ hybrid, which is an intermediate-day cultivar for fall transplanting; Takii, Kyoto, Japan) and 'Katamaru' (an $F_{1}$ hybrid, which is an intermediate-day cultivar for fall transplanting; Haesung Seed Plus Co., Busan, South Korea). Individual onion plots were $3 \mathrm{~m}$ long, accommodating 150 plants in $4.5 \mathrm{~m}^{2}$.

NPP (Yeongnong Industry, Jinju, South Korea) with a weight of $18 \mathrm{~g} \cdot \mathrm{m}^{-2}$ and width of $1.6 \mathrm{~m}$ was placed on all plots on $1 \mathrm{Dec}$. and removed on $28 \mathrm{Feb}$. The NPP was fixed with plastic pins at 2-m intervals.

Meteorological and soil environments. The average daily air temperature, average relative humidity, total sunshine duration, and rainfall during different growth stages of each year were obtained from annual reports presented by the regional weather station in Hapcheon county (lat. $35^{\circ} 56^{\prime} 51^{\prime \prime} \mathrm{N}$, long. $128^{\circ} 16^{\prime} 99^{\prime \prime} \mathrm{E}, 32 \mathrm{~m}$ ), which was operated by KMA (2018).

Root zone temperature and soil moisture potential during the growing seasons were measured by determining the soil tempera- ture and moisture potential midway between the plants at $10 \mathrm{~cm}$ below the mulch or soil surface. The temperature and moisture potential were measured with a Mini-logger (PlantCare Ltd., Russikon Switzerland). The data logger was programmed to record and store readings every hour for each plot.

Plant characteristics and bulb yield determination. Ten plants were randomly collected from three replications at transplanting on 4 Apr. and on 5 May. After measuring the plant length from the stem to the tip of the longest green leaf, measuring the bulb diameter, and counting the number of leaves, onion plants were separated at the leaf sheath base into the leaf and root, and their weights were measured for seedling characteristics. To measure the mid vegetative growth and mid bulb development stages, onion plants were separated at the leaf sheath base into the leaf and root, and the leaves were separated at the neck from the bulbs. Then, their weights were measured.

At harvest time, onions were collected by hand from $1.80 \mathrm{~m}^{2}(1.50 \mathrm{~m} \times 1.20 \mathrm{~cm})$, with 72 transplanting holes in three replications. Harvested onion plants were separated into bulbs and leaves. All leaves were weighed in the fields, and all of the harvested onion bulbs were individually weighed. Bolted, doubled, and rotten onions were culled because they were unmarketable. Marketable bulbs were distributed in the following size classes based on their diameter: smaller than $60 \mathrm{~mm}$ (small); 60 to smaller than $80 \mathrm{~mm}$ (medium); and larger than $80 \mathrm{~mm}$ (large). The yield of each sample area was converted to the total bulb weight per hectare. Stand reduction was calculated as the percentage of onion plants lost from 72 transplanting holes.

Data analysis. Data were analyzed with a four-way analysis of variance (ANOVA) using a split-plot design and XLSTAT base (annual version 2018.5; Addinsoft, New York, NY). The model included the year, cultivar, transplanting date, and mulch type, as well as their interactions. Effects with Ftest probability values $>0.05$ were considered nonsignificant.

\section{Results and Discussion}

Meteorological and soil conditions. Mean daily air temperature, cumulative temperature, and growing degree days were similar during each growing season (Table 1). However, there were differences in the daily air temperatures during different growth stages during the two different growing seasons (Table 2). Mean and minimum daily air temperatures of the transplanting and root establishment stages (from early November to early December) were 2.6 and $4.3{ }^{\circ} \mathrm{C}$, higher in 2015 than in 2016, respectively. Mean and minimum temperatures during the vegetative growth stage (from mid February to mid April) were 0.4 and $1.5^{\circ} \mathrm{C}$, higher in 2016 than in 2017, respectively. In contrast, the mean and minimum temperatures of the sowing and seedling stages (from early September to late October) were 1.5 and $3.6^{\circ} \mathrm{C}$, 
Table 1. Sowing, transplanting, and harvest dates and weather conditions during the growing seasons of different years and experimental locations.

\begin{tabular}{lcccccc}
\hline Yr & Sowing date & Harvest date & Avg temp $\left({ }^{\circ} \mathrm{C}\right)^{\mathrm{z}}$ & ${\text { Cumulative temp }\left({ }^{\circ} \mathrm{C}\right)^{\mathrm{z}}}$ & Growing degree days $^{\mathrm{y}}$ & ${\text { Total rainfall }(\mathrm{mm})^{\mathrm{x}}}$ \\
\hline $2015 / 2016$ & 5 Sept. & 7 June & 10.1 & 2,788 & 1,866 & 767 \\
$2016 / 2017$ & 5 Sept. & 7 June & 10.2 & 2,798 & 1,863 & 609 \\
\hline
\end{tabular}

${ }^{\mathrm{z}}$ Calculated as the average and sum of the average daily air temperature during the period from onion seed sowing to harvest.

${ }^{\mathrm{y}} \mathrm{Calculated}$ as the sum of the average daily air temperature more than $4{ }^{\circ} \mathrm{C}$ during the period from onion seed sowing to harvest.

${ }^{\mathrm{x}}$ Calculated as the sum of rainfall during the period from onion seed sowing to harvest.

Table 2. Mean daily air temperature and relative humidity and total sunshine duration and rainfall of growth stages during the growing seasons in $2015 / 2016$ and 2016/2017.

\begin{tabular}{|c|c|c|c|c|c|c|c|}
\hline & Yr & $\begin{array}{l}\text { Early Sept. to } \\
\text { late Oct. (sowing } \\
\text { and seedling) }\end{array}$ & $\begin{array}{c}\text { Early Nov. to } \\
\text { early Dec. } \\
\text { (transplanting and } \\
\text { root development) }\end{array}$ & $\begin{array}{c}\text { Mid Dec. to } \\
\text { early Feb. } \\
\text { (overwintering) }\end{array}$ & $\begin{array}{l}\text { Mid Feb. to } \\
\text { mid Apr. } \\
\text { (vegetative } \\
\text { growth) }\end{array}$ & $\begin{array}{c}\text { Late Apr. to } \\
\text { early June } \\
\text { (bulb development) }\end{array}$ & Avg \\
\hline \multirow[t]{3}{*}{ Mean temperature $\left({ }^{\circ} \mathrm{C}\right)$} & $2015 / 2016$ & 17.1 & 9.0 & 0.3 & 8.1 & 18.6 & 11.2 \\
\hline & $2016 / 2017$ & 18.7 & 6.4 & 1.1 & 7.7 & 19.0 & 11.3 \\
\hline & 30-year average & 17.5 & 6.3 & 0.2 & 7.1 & 17.9 & 10.5 \\
\hline \multirow[t]{3}{*}{ Maximum temperature $\left({ }^{\circ} \mathrm{C}\right)$} & $2015 / 2016$ & 24.9 & 14.3 & 7.1 & 15.0 & 26.1 & 18.1 \\
\hline & $2016 / 2017$ & 23.8 & 13.9 & 8.2 & 15.0 & 27.2 & 18.4 \\
\hline & 30-year average & 24.5 & 14.2 & 7.5 & 14.3 & 25.1 & 17.7 \\
\hline \multirow[t]{3}{*}{ Minimum temperature $\left({ }^{\circ} \mathrm{C}\right)$} & $2015 / 2016$ & 11.5 & 4.9 & -5.1 & 2.1 & 11.7 & 5.6 \\
\hline & $2016 / 2017$ & 15.1 & 0.6 & -4.8 & 0.6 & 10.9 & 5.2 \\
\hline & 30-year average & 12.2 & 0.4 & -5.6 & 0.6 & 11.0 & 4.5 \\
\hline \multirow[t]{3}{*}{ Relative humidity (\%) } & $2015 / 2016$ & 71.9 & 76.8 & 61.6 & 56.3 & 61.3 & 64.9 \\
\hline & $2016 / 2017$ & 80.3 & 67.9 & 57.1 & 52.0 & 52.3 & 61.3 \\
\hline & 30-year average & 73.6 & 68.5 & 63.6 & 60.1 & 63.1 & 65.9 \\
\hline \multirow[t]{3}{*}{ Sunshine duration (h) } & $2015 / 2016$ & 403.3 & 124.3 & 370.6 & 480.1 & 386.4 & 187.4 \\
\hline & $2016 / 2017$ & 221.8 & 226.2 & 387.8 & 527.2 & 465.6 & 198.8 \\
\hline & 30-year average & 372.4 & 233.1 & 380.4 & 471.7 & 372.4 & 194.3 \\
\hline \multirow[t]{3}{*}{ Rainfall (mm) } & $2015 / 2016$ & 128.5 & 117.4 & 45.7 & 255.1 & 177.7 & 76.7 \\
\hline & $2016 / 2017$ & 539.7 & 15.5 & 72.7 & 98.1 & 40.2 & 92.0 \\
\hline & 30-year average & 200.3 & 39.5 & 35.2 & 133.7 & 155.3 & 70.4 \\
\hline
\end{tabular}

lower in 2015 than in 2016, respectively. The mean and maximum temperatures of the overwintering stage (from mid December to early February) were 0.8 and $1.1^{\circ} \mathrm{C}$, lower in $2015 / 2016$ than in $2016 / 2017$, respectively. In addition, the mean and maximum temperatures of the bulb development stage (from mid April to early June) were 0.4 and $1.1{ }^{\circ} \mathrm{C}$, lower in $2015 / 2016$ than in $2016 /$ 2017 , respectively. Total rainfall was increased in 2015/2016 (767 mm) compared to that in 2016/2017 (609 mm) (Table 1). Rainfall levels during transplanting, vegetative growth, and bulb development stages were $101.9,157.0$, and $137.5 \mathrm{~mm}$ more in $2015 / 2016$ than in 2016/2017, respectively; however, rainfall levels during the seedling and overwintering stages were $411.2 \mathrm{~mm}$ and $27.0 \mathrm{~mm}$ less in $2015 / 2016$ than in $2016 / 2017$, respectively. The relative humidity levels during overwintering, vegetative growth, and bulb development stages were $6.5 \%, 8.1 \%$, and $10.7 \%$ lower in 2015 / 2016 than in $2016 / 2017$, respectively. In contrast, the total hours of sunshine during overwintering, vegetative growth, and bulb development stages were 7.4, 55.5, and $93.2 \mathrm{~h}$ longer in 2015/2016 than in 2016/2017, respectively.

The minimum temperature for leaf growth is $10^{\circ} \mathrm{C}$, with favorable temperatures ranging from 17 to $25^{\circ} \mathrm{C}$ (Kato, 1963). Bulb formation is promoted by long days and high temperatures (Kato, 1963; Magruder and Allard, 1937). Coolong and Randle (2003) reported that fresh bulb weight was highest for mature plants grown at $22.1{ }^{\circ} \mathrm{C}$; however, it decreased at higher temperatures. Exces- sive vegetative growth during root development or during the overwintering vegetative growth period as well as low temperatures during early spring could cause doubled onion bulbs or inflorescence initiation (bolting), resulting in unmarketable bulbs. In overwintering onions, doubled bulbs are promoted by more than 10 total differentiated leaves and a sheath diameter of more than $7.0 \mathrm{~mm}$ during November and early December (Kato et al., 1999; Lee, 2015). Therefore, high temperatures during the late seedling stage, transplanting, and root development can increase doubled onion bulbs. Bolting is promoted by more than nine total differentiated leaves and a sheath diameter of more than $10.0 \mathrm{~mm}$ from late February to mid March (Brewster, 1985; Kato et al., 1999; Lee, 2015). Inflorescence initiation is affected by low temperatures during early spring as well as seedling size at transplanting and excessive plant growth during warm winters. Even though the temperature needed for inflorescence initiation varies with the cultivar and growing region (Brewster, 2008), the optimum temperature range for overwintered fall-sown cultivars is known to be 0 to $10^{\circ} \mathrm{C}$ (Ito, 1956; Shishido and Saito, 1975). The larger the sheath diameter, the shorter the period of exposure to low temperatures required for inflorescence initiation (Shishido and Saito, 1976).

Soil temperature and water potential at a depth of $10 \mathrm{~cm}$ during the 2016/2017 growing season are shown in Figs. 1 and 2. NPP covering from $1 \mathrm{Dec}$. to $28 \mathrm{Feb}$. with no plastic mulch increased soil temperature by $2.1{ }^{\circ} \mathrm{C}$ compared with bare ground. Soil temperatures with black and transparent plastic mulch were 0.7 and $1.7{ }^{\circ} \mathrm{C}$ higher, respectively, than when there was no plastic mulch when covered with NPP from 1 Dec. to $28 \mathrm{Feb}$. The average soil water potential from early October to early June were $-7.1 \mathrm{kPa}$ with no mulch, $-8.1 \mathrm{kPa}$ with no mulch and NPP, and $4.0 \mathrm{kPa}$ and $2.8 \mathrm{kPa}$ higher with black mulch and transparent mulch, respectively, compared with no mulch with NPP. The soil water potential with no mulch with NPP decreased to less than $-10 \mathrm{kPa}$ more frequently than with other treatments; however, the soil water potential with transparent mulch and black mulch with NPP continued to $-10 \mathrm{kPa}$ until mid April, and with black mulch and NPP it continued until mid March.

Soil temperature and moisture content with transparent mulch, black mulch, or NPP covering during the onion growing season were higher than when no mulch was used (Diaz-Perez et al., 2004; Siwek et al., 2013; Suh and Kim, 1991). Using a plastic mulch or covering is particularly effective for increasing soil temperatures during overwintering and for enhancing the initial vegetative growth of overwintered onions (Suh and Kim, 1991; Suh et al., 1991). Brewster (2008) reported that a covering of polyethylene mulch with 500 perforations with a diameter of $1 \mathrm{~cm} / \mathrm{m}^{2}$ or NPP fabric increased the mean soil temperature by 1 to $2{ }^{\circ} \mathrm{C}$, resulting in faster growth and earlier harvest. However, when the air temperatures during late autumn and winter are higher than the temperatures of an average year, plastic mulch could increase doubled and bolted bulbs (Diaz-Perez et al., 2004; Suh 


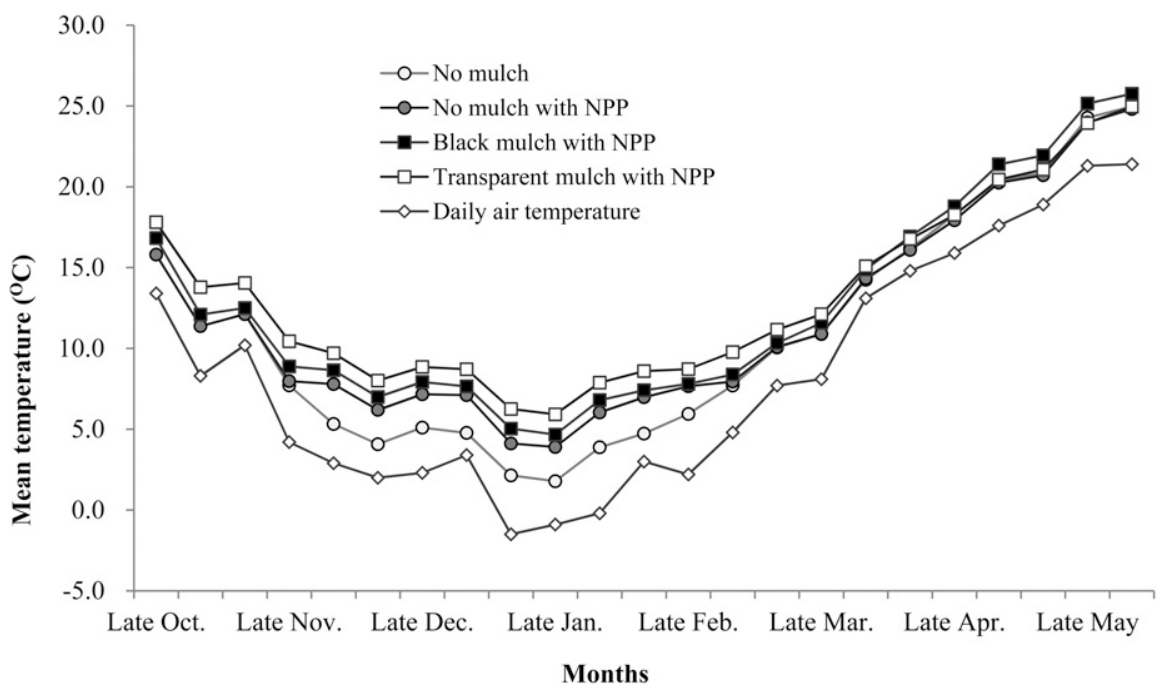

Fig. 1. Mean daily root zone temperatures for no mulch, no mulch with a nonwoven polypropylene (NPP) covering from 1 Dec. to 28 Feb., transparent mulch with NPP, and black mulch with NPP, and the mean daily air temperature at 10-d intervals during the onion growing season of 2016/2017.

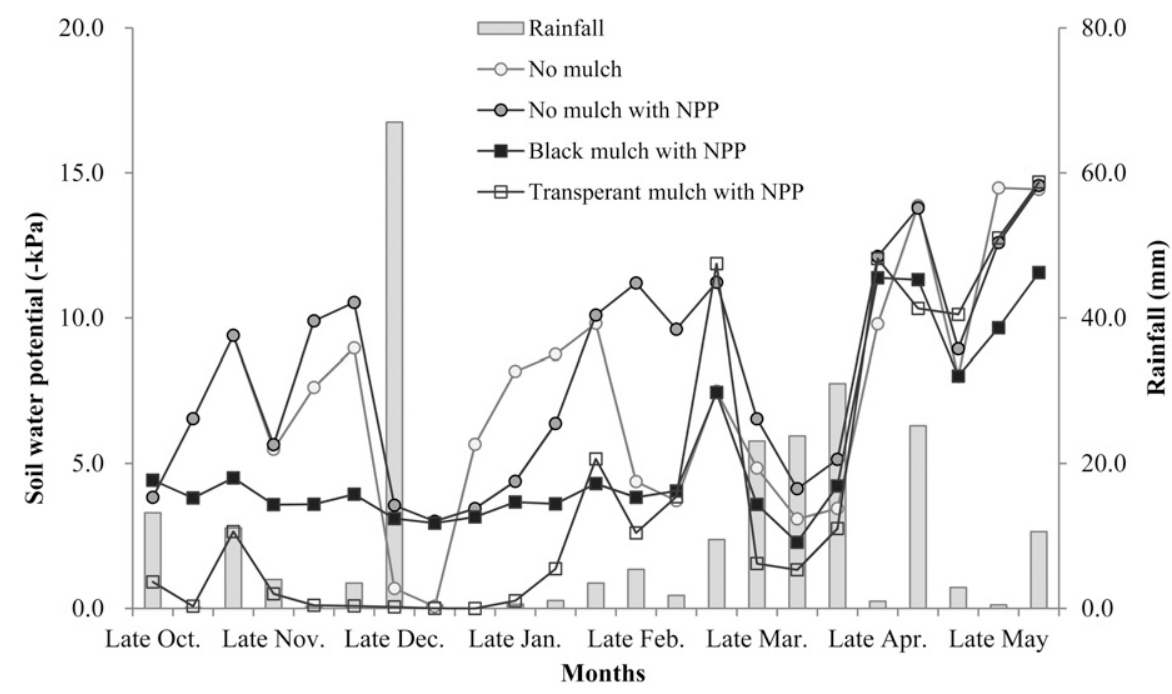

Fig. 2. Mean daily soil moisture potentials of no mulch, no mulch with a nonwoven polypropylene (NPP) converging from 1 Dec. to 28 Feb., transparent mulch with NPP, and black mulch with NPP, and the 10-d rainfall values during the onion growing season of 2016/2017.

and Kim, 1992). When using the NPP covering with different mulch types from early December to late February, the soil temperature increased by $2.1^{\circ} \mathrm{C}$ at a depth of $10 \mathrm{~cm}$ with no mulch, by $2.8^{\circ} \mathrm{C}$ with black plastic mulch, and by $3.9^{\circ} \mathrm{C}$ with transparent mulch compared with the no NPP covering and no mulch. Therefore, NPP could increase the total bulb yield, but with a considerable risk of increasing the unmarketable bulb yield depending on the weather conditions during transplanting and growth.

Onions are sensitive to small water deficits and require frequent irrigation to maintain their high soil water potential during growth, particularly during bulb formation (Enciso et al., 2009; Shock et al., 1998). Water deficiency during bulb development can reduce onion yield more than what can occur during the vegetative stage (Dragland, 1974; Van Eeden and Myburgh, 1971). Soil water tension as irrigation criteria for shortday onions varied from -8.5 to $-45 \mathrm{kPa}$ depending on the climate, soil type, and irrigation system, and the irrigation criterion for long-day onions on silt loam varied from -10 to $-27 \mathrm{kPa}$ (Shock and Wang, 2011). Because the most commonly used soil type is silt loam, and because the maximum air temperature increases to more than $20{ }^{\circ} \mathrm{C}$ after mid April in southeastern Korea, irrigation could be necessary when soil water tension reaches -10 to $-15 \mathrm{kPa}$, which corresponds to conditions from late April to harvest. The agricultural practices of conventional onion farmers do not commonly include furrow or sprinkler irrigation; these are not recommended because excessive soil moisture could negatively affect root vitality and increase disease pressure on developing bulbs. Therefore, further research of irrigation is necessary to improve onion bulb pro- ductivity against climate change, particularly in a production system without mulch.

Seedling characteristics. The numbers of leaves, bulb diameters, and root and bulb fresh weights were significantly different between the two growing seasons and two cultivars, and among the three transplanting dates (Table 3). Seedlings grown in 2015 had significantly greater numbers of leaves, bulb diameters, and root and bulb fresh weights than those grown in 2016. Lower mean daily air temperature, lower relative humidity, greater sunshine duration, less rainfall during the seedling stage in 2015 compared with that in 2016 may have improved onion seedling growth. Kato et al. (1999) reported that the plant height of onion seedlings (seedling height of $10 \mathrm{~cm}$ ) grown at a constant temperature of $25{ }^{\circ} \mathrm{C}$ was greater than that of seedlings grown at $17^{\circ} \mathrm{C}$ for $15 \mathrm{~d}$; however, the relative growth rate of onion seedlings at $17{ }^{\circ} \mathrm{C}$ was higher than at $25^{\circ} \mathrm{C}$ after $9 \mathrm{~d}$. In addition, heavy and frequent rain and high temperatures could increase damping-off and root stress, thus affecting plant growth (Lee et al., 2017; Schwartz and Mohan, 2008).

The root fresh weight at transplanting increased with seedling age. However, the number of leaves, plant heights, bulb diameters, and leaf weight were not different between 5 Nov. and 20 Nov., or they were decreased on 20 Nov. There were some differences in seedling characteristics between the two cultivars. The cultivar Sunpower had a greater bulb diameter and leaf weight than the cultivar Katamaru; however, it had fewer leaves and a smaller root weight. In addition, the bulb diameter and root weight of 'Sunpower' was smaller than that of 'Katamaru' in 2015, but it was greater in 2016. This might be attributable to the different responses of the two cultivars to different weather conditions. The plant heights and leaf weights of seedlings in 2015 increased with seedling age or remained similar between 5 Nov. and 20 Nov., but it was decreased on 20 Nov. as compared with 5 Nov. in 2016. Lower mean air temperature during mid Nov. $2016\left(7.2^{\circ} \mathrm{C}\right)$ as compared with that during $2015\left(12.7^{\circ} \mathrm{C}\right)$ resulted in differences in seedling growth between these two seasons.

Onion growth characteristics. The numbers of leaves, bulb diameters, and root, leaf, and bulb weights were significantly greater during the 2015/2016 growing season than during the 2016/2017 growing season, and were significantly greater for 'Sunpower' than for 'Katamaru' on 4 Apr. (Table 4). Onion plants transplanted on 20 Oct. were larger than those transplanted on 5 Nov. or 20 Nov. Onion plants grown with transparent plastic mulch were larger than ones grown with black mulch or no mulch. Regarding the combination effect of year and cultivar, the numbers of leaves, plant heights, bulb diameters, and root, leaf, and bulb weights of 'Sunpower' were significantly greater than those of 'Katamaru' during the 2015/2016 growing season; however, there were no differences between the two cultivars during 


\begin{tabular}{|c|c|c|c|c|c|c|c|c|}
\hline \multirow[b]{2}{*}{$\mathrm{Yr}$} & \multirow[b]{2}{*}{ Cultivar } & \multirow[b]{2}{*}{ Transplanting date } & \multirow[b]{2}{*}{ No. of leaves } & \multirow[b]{2}{*}{ Plant ht $(\mathrm{cm})$} & \multirow[b]{2}{*}{ Bulb diam $(\mathrm{mm})$} & \multicolumn{3}{|c|}{ Fresh wt (g/plant) } \\
\hline & & & & & & Root & Leaf & $\mathrm{L} / \mathrm{R}^{\mathrm{z}}$ \\
\hline \multirow{4}{*}{$2015 / 2016$} & & 5 Nov. & 4.6 & 40.1 & 9.4 & 0.30 & 8.1 & 27.0 \\
\hline & & 20 Nov. & 4.6 & 42.8 & 9.9 & 0.67 & 7.6 & 11.4 \\
\hline & & 5 Nov. & 4.6 & 39.5 & 11.5 & 0.60 & 7.8 & 12.9 \\
\hline & & 20 Nov. & 4.8 & 41.2 & 11.0 & 0.85 & 7.8 & 9.2 \\
\hline \multirow[t]{4}{*}{$2016 / 2017$} & Sunpower & 20 Oct. & 3.2 & 28.9 & 4.2 & 0.07 & 1.6 & 26.3 \\
\hline & Katamaru & 20 Oct. & 3.8 & 32.3 & 4.7 & 0.13 & 2.2 & 17.4 \\
\hline & & 5 Nov. & 4.4 & 34.7 & 6.2 & 0.15 & 3.7 & 24.1 \\
\hline & & 20 Nov. & 3.3 & 23.9 & 6.7 & 0.18 & 2.2 & 11.6 \\
\hline \multicolumn{9}{|l|}{ F-test } \\
\hline \multicolumn{3}{|l|}{ Year (Y) } & ** & ** & ** & ** & ** & NS \\
\hline \multicolumn{2}{|c|}{ Cultivar (C) } & & ** & NS & $*$ & $* *$ & $* *$ & ** \\
\hline \multicolumn{2}{|c|}{ Transplanting date $(\mathrm{T})$} & & ** & ** & ** & ** & ** & ** \\
\hline
\end{tabular}

${ }^{\mathrm{z}} \mathrm{L} / \mathrm{R}$ : leaf-to-root ratio.

All seedlings were sown on 5 Sept.

Ns, * **Nonsignificant or significant at $P \leq 0.05$ or 0.01 , respectively.

Table 4. Onion plant growth characteristics as affected by cultivars, transplanting times, and mulch types during the mid vegetative growth stage (4 Apr.).

\begin{tabular}{|c|c|c|c|c|c|c|c|c|c|c|c|c|c|c|}
\hline \multirow[b]{3}{*}{ Cultivar } & \multirow[b]{3}{*}{ Transplanting date } & \multirow[b]{3}{*}{ Mulch type } & \multicolumn{6}{|c|}{$2015 / 2016$} & \multicolumn{6}{|c|}{$2016 / 2017$} \\
\hline & & & \multirow{2}{*}{$\begin{array}{l}\text { No. of } \\
\text { leaves }\end{array}$} & \multirow{2}{*}{$\begin{array}{l}\text { Plant } \\
\text { ht }(\mathrm{cm})\end{array}$} & \multirow{2}{*}{$\begin{array}{c}\text { Bulb } \\
\operatorname{diam}(\mathrm{mm})\end{array}$} & \multicolumn{3}{|c|}{ Fresh wt (g/plant) } & \multirow[b]{2}{*}{ No. of leaves } & \multirow{2}{*}{$\begin{array}{l}\text { Plant } \\
\text { ht }(\mathrm{cm})\end{array}$} & \multirow{2}{*}{$\begin{array}{c}\text { Bulb } \\
\operatorname{diam}(\mathrm{mm})\end{array}$} & \multicolumn{3}{|c|}{ Fresh wt (g/plant) } \\
\hline & & & & & & Root & Bulb & Leaf & & & & Root & Bulb & Leaf \\
\hline \multirow[t]{6}{*}{ Sunpower } & 20 Oct. & Transparent & 9.7 & 58.5 & 31.7 & 5.6 & 26.8 & 67.0 & 6.8 & 45.1 & 22.7 & 2.6 & 13.7 & 30.6 \\
\hline & & No mulch & 8.1 & 59.5 & 26.6 & 4.7 & 18.7 & 64.4 & 5.5 & 36.3 & 15.2 & 1.2 & 5.4 & 15.5 \\
\hline & 5 Nov. & Transparent & 7.7 & 60.9 & 31.3 & 4.5 & 22.8 & 73.7 & 6.1 & 36.9 & 17.0 & 1.8 & 7.0 & 15.4 \\
\hline & & Black & 7.1 & 47.7 & 23.7 & 4.2 & 13.1 & 34.5 & 5.3 & 36.0 & 13.6 & 1.0 & 4.7 & 11.9 \\
\hline & & No mulch & 7.0 & 46.9 & 27.9 & 3.7 & 17.9 & 40.3 & 5.5 & 34.9 & 14.4 & 1.0 & 5.0 & 12.5 \\
\hline & & No mulch & 8.0 & 63.6 & 27.5 & 4.2 & 20.4 & 72.0 & 4.7 & 23.9 & 10.8 & 0.6 & 2.4 & 4.5 \\
\hline \multirow[t]{6}{*}{ Katamaru } & 20 Oct. & Transparent & 7.8 & 61.2 & 30.6 & 2.2 & 24.8 & 77.1 & 7.1 & 47.3 & 20.7 & 2.2 & 9.7 & 27.4 \\
\hline & & Black & 7.2 & 49.3 & 25.1 & 1.7 & 15.5 & 35.2 & 6.0 & 44.1 & 16.6 & 1.1 & 7.1 & 20.3 \\
\hline & & No mulch & 6.6 & 43.1 & 24.3 & 2.0 & 13.6 & 29.3 & 5.5 & 36.5 & 14.0 & 1.0 & 4.8 & 13.3 \\
\hline & 5 Nov. & Transparent & 7.3 & 50.7 & 20.6 & 2.2 & 10.8 & 31.1 & 6.5 & 39.9 & 16.2 & 1.5 & 6.2 & 16.5 \\
\hline & & Black & 6.7 & 40.6 & 21.3 & 1.7 & 10.2 & 22.3 & 5.8 & 37.9 & 12.9 & 0.9 & 4.3 & 11.4 \\
\hline & & No mulch & 7.2 & 54.3 & 19.5 & 2.0 & 10.3 & 32.2 & 5.8 & 34.3 & 13.7 & 1.0 & 4.5 & 11.5 \\
\hline \multicolumn{2}{|l|}{ Year (Y) } & & $* *$ & ** & ** & ** & ** & ** & & & & & & \\
\hline \multicolumn{2}{|c|}{ Cultivar (C) } & & $* *$ & NS & ** & ** & ** & $* *$ & & & & & & \\
\hline \multicolumn{2}{|c|}{ Transplanting date $(\mathrm{T})$} & & ** & ** & * & ** & ** & ** & & & & & & \\
\hline \multicolumn{2}{|c|}{ Mulch type (M) } & & ** & ** & ** & ** & ** & ** & & & & & & \\
\hline \multicolumn{2}{|c|}{$\mathrm{Y}^{*} \mathrm{C}$} & & ** & $*$ & ** & ** & ** & ** & & & & & & \\
\hline \multicolumn{2}{|l|}{$\mathrm{Y}^{* \mathrm{~T}}$} & & ** & ** & * & ** & ** & ** & & & & & & \\
\hline \multicolumn{2}{|l|}{$\begin{array}{l}\mathrm{Y} * \mathrm{M} \\
\mathrm{C} * \mathrm{~T}\end{array}$} & & NS & $* *$ & NS & NS & NS & NS & & & & & & \\
\hline $\mathrm{C}^{*} \mathrm{~T}$ & & & ** & NS & NS & NS & $*$ & $*$ & & & & & & \\
\hline \multicolumn{2}{|l|}{$\mathrm{C}^{*} \mathrm{M}$} & & NS & NS & NS & NS & NS & NS & & & & & & \\
\hline $\mathrm{T} * \mathrm{M}$ & & & NS & NS & NS & NS & $* *$ & $*$ & & & & & & \\
\hline $\mathrm{Y}^{*} \mathrm{C}^{*} \mathrm{~T}$ & & & $* *$ & NS & $*$ & $*$ & ** & $* *$ & & & & & & \\
\hline $\mathrm{Y}^{*} \mathrm{C}^{*} \mathrm{M}$ & & & NS & NS & NS & NS & $*$ & NS & & & & & & \\
\hline $\mathrm{Y} * \mathrm{~T} * \mathrm{M}$ & & & NS & NS & NS & NS & NS & NS & & & & & & \\
\hline $\mathrm{C}^{*} \mathrm{~T} * \mathrm{M}$ & & & NS & NS & NS & NS & $*$ & ** & & & & & & \\
\hline
\end{tabular}

${ }^{\mathrm{z}}$ Statistics came from the $2015 / 2016$ and $2016 / 2017$ growing seasons.

Ns, *, **Nonsignificant or significant at $P \leq 0.05$ or 0.01 , respectively.

2016/2017. During the 2016/2017 growing season, onion plants transplanted earlier were larger than those transplanted later; however, in $2015 / 2016$, there were no such differences between 5 Nov. and 20 Nov. There was no combination effect of the numbers of leaves, bulb diameters, and root, bulb, and leaf fresh weights between years and among mulch types, or between cultivars and transplanting times. In addition, the numbers of leaves as well as the fresh bulb and leaf weights of 'Katamaru' were greater with earlier transplanting during both growing seasons, whereas those of 'Sunpower' were not dif- ferent between 20 Oct. and 20 Nov. during the 2015/2016 growing season.

However, the growth characteristics of onion plants on 5 May were slightly different than the previous results (Table 5). The numbers of leaves as well as the root and leaf fresh weights were greater during the 
Table 5. Onion plant characteristics as affected by cultivars, transplanting times, and mulch types during the mid bulb development stage (5 May).

\begin{tabular}{|c|c|c|c|c|c|c|c|c|c|c|c|c|c|c|}
\hline \multirow{2}{*}{ Cultivar } & \multirow{2}{*}{$\begin{array}{l}\text { Transplanting } \\
\text { date }\end{array}$} & \multirow{2}{*}{ Mulch type } & \multicolumn{6}{|c|}{$2015 / 2016$} & \multicolumn{6}{|c|}{$2016 / 2017$} \\
\hline & & & $\begin{array}{l}\text { No. of } \\
\text { leaves }\end{array}$ & $\begin{array}{l}\text { Plant } \\
\text { ht }(\mathrm{cm})\end{array}$ & $\begin{array}{c}\text { Bulb } \\
\operatorname{diam}(\mathrm{mm})\end{array}$ & \multicolumn{3}{|c|}{ Fresh wt (g/plant) } & $\begin{array}{l}\text { No. of } \\
\text { leaves }\end{array}$ & $\begin{array}{l}\text { Plant } \\
\text { ht }(\mathrm{cm})\end{array}$ & $\begin{array}{c}\text { Bulb } \\
\text { diam (mm) }\end{array}$ & \multicolumn{3}{|c|}{ Fresh wt (g/plant) } \\
\hline \multirow[t]{6}{*}{ Sunpower } & 20 Oct. & Transparent & 8.5 & 67.3 & 50.5 & 2.4 & 89.6 & 90.4 & 8.2 & 78.0 & 54.9 & 2.3 & 105.9 & 85.2 \\
\hline & & No mulch & 7.7 & 61.9 & 39.9 & 1.8 & 50.3 & 63.8 & 7.6 & 69.0 & 50.5 & 1.7 & 78.7 & 61.0 \\
\hline & 5 Nov. & Transparent & 8.6 & 72.3 & 49.3 & 2.1 & 82.5 & 90.0 & 8.2 & 76.5 & 50.0 & 2.0 & 79.3 & 71.4 \\
\hline & & Black & 9.0 & 79.1 & 56.3 & 2.8 & 115.9 & 126.6 & 7.7 & 75.2 & 51.2 & 1.2 & 86.4 & 70.3 \\
\hline & & No mulch & 8.9 & 64.5 & 44.4 & 2.4 & 60.7 & 81.3 & 7.7 & 75.7 & 49.8 & 1.9 & 77.7 & 71.2 \\
\hline & & No mulch & 8.2 & 63.2 & 39.3 & 1.0 & 46.5 & 65.7 & 7.1 & 66.3 & 40.0 & 1.2 & 45.3 & 45.8 \\
\hline \multirow[t]{6}{*}{ Katamaru } & 20 Oct. & Transparent & 10.3 & 76.0 & 50.2 & 3.2 & 90.9 & 125.1 & 9.4 & 83.0 & 57.6 & 3.2 & 128.5 & 121.7 \\
\hline & & Black & 9.5 & 81.9 & 52.0 & 2.9 & 106.3 & 151.0 & 8.7 & 79.7 & 58.6 & 2.4 & 134.0 & 98.7 \\
\hline & & No mulch & 9.7 & 72.5 & 43.5 & 2.4 & 58.4 & 98.2 & 8.5 & 71.8 & 49.7 & 1.8 & 79.5 & 73.6 \\
\hline & 5 Nov. & Transparent & 11.1 & 85.8 & 56.1 & 3.1 & 121.0 & 168.6 & 8.7 & 77.5 & 49.7 & 2.1 & 85.3 & 75.7 \\
\hline & & Black & 9.7 & 84.8 & 52.6 & 1.9 & 108.2 & 154.1 & 8.2 & 77.5 & 49.8 & 1.9 & 87.8 & 75.6 \\
\hline & & No mulch & 9.3 & 71.4 & 39.5 & 2.3 & 52.1 & 96.3 & 8.5 & 73.3 & 50.6 & 2.1 & 84.6 & 74.2 \\
\hline \multicolumn{3}{|c|}{ Year (Y) } & $* *$ & NS & ** & * & NS & ** & & & & & & \\
\hline \multicolumn{3}{|c|}{ Cultivar (C) } & $* *$ & $* *$ & NS & * & $*$ & ** & & & & & & \\
\hline \multicolumn{3}{|c|}{ Transplanting date $(\mathrm{T})$} & ** & ** & $* *$ & ** & ** & ** & & & & & & \\
\hline \multicolumn{3}{|c|}{ Mulch type (M) } & $* *$ & $* *$ & $* *$ & $*$ & $* *$ & $* *$ & & & & & & \\
\hline \multicolumn{3}{|c|}{$\mathrm{Y}^{*} \mathrm{C}$} & $*$ & $*$ & NS & NS & NS & ** & & & & & & \\
\hline \multicolumn{3}{|l|}{$\mathrm{Y}^{*} \mathrm{~T}$} & NS & NS & $*$ & NS & ** & ** & & & & & & \\
\hline \multicolumn{3}{|l|}{$\mathrm{Y} * \mathrm{M}$} & NS & $* *$ & $*$ & NS & $*$ & $* *$ & & & & & & \\
\hline $\mathrm{C}^{*} \mathrm{~T}$ & & & $*$ & NS & NS & NS & NS & $*$ & & & & & & \\
\hline $\mathrm{C}^{*} \mathrm{M}$ & & & NS & NS & NS & NS & NS & $*$ & & & & & & \\
\hline $\mathrm{T} * \mathrm{M}$ & & & NS & NS & NS & NS & NS & NS & & & & & & \\
\hline $\mathrm{Y}^{*} \mathrm{C} * \mathrm{~T}$ & & & NS & NS & NS & NS & NS & NS & & & & & & \\
\hline $\mathrm{Y}^{*} \mathrm{C} * \mathrm{M}$ & & & NS & NS & NS & NS & NS & NS & & & & & & \\
\hline $\mathrm{Y} * \mathrm{~T} * \mathrm{M}$ & & & NS & NS & NS & NS & NS & $*$ & & & & & & \\
\hline $\mathrm{C}^{*} \mathrm{~T} * \mathrm{M}$ & & & NS & NS & NS & NS & NS & NS & & & & & & \\
\hline
\end{tabular}

${ }^{\mathrm{z}}$ Statistics came from the 2015/2016 and 2016/2017 growing seasons.

Ns, *, **Nonsignificant or significant at $P \leq 0.05$ or 0.01 , respectively.

2015/2016 growing season than during 2016/ 2017 , but the bulb diameter was greater in $2016 / 2017$ than in $2015 / 2016$. Numbers of leaves, plant heights, and root, leaf, and bulb weights of 'Katamaru' were significantly greater than those of 'Sunpower', which contrasted with the results of 4 Apr. Growth characteristics of onion plants transplanted on 20 Oct. and 5 Nov. were not significantly different from each other, but they were greater than those transplanted on 20 Nov. Numbers of leaves and root fresh weights were greater for onion plants grown with transparent plastic mulch than for those grown with black mulch; however, plant height was greater with black mulch than with transparent mulch. There was no combination effect of year and cultivar, and the number of leaves and plant and leaf fresh weight of 'Katamaru' were greater than those of 'Sunpower'. Bulb and leaf fresh weights were not different between onions transplanted on 20 Oct. and 5 Nov. during the 2015/2016 growing season, whereas those transplanted on 20 Oct. had greater values than those transplanted in November 2016/ 2017. Plant heights and leaf fresh weights of onions grown with black plastic mulch were greater than those grown with transparent mulch during 2015/2016; however, there were no differences between those grown with black mulch and transparent mulch during 2016/2017.
The significant increase in onion plants grown during the 2015/2016 growing season compared with the $2016 / 2017$ growing season should be attributed to the higher mean and minimum air temperatures as well as the greater seedling size during 2015/2016. These conditions affected onion growth until the mid bulb development stage, but the differences between the two growing seasons were not greater at the later growth stage compared with the mid vegetative growth stage. 'Sunpower' was larger at the seedling and mid vegetative growth stages compared with 'Katamaru'; however, at the mid bulb development stage, 'Katamaru' was larger than 'Sunpower'. This result might be due to the maturity of the cultivars, which affects their response to temperature and sunshine duration. The bulbing ratio is one method of determining the degree of maturity of onion cultivars, which is calculated by the ratio of the maximum bulb diameter to the minimum sheath diameter (Brewster, 2008). Bulbing ratios greater than 2 were commonly used to define bulb initiation. On 5 May, the bulbing ratio of 'Sunpower' (3.1) was greater than that of 'Katamaru' (2.9). This indicated that 'Sunpower' is more precocious than 'Katamaru'. Additionally, 'Sunpower' is characterized by faster growth when young plants are grown under high temperatures compared with 'Katamaru'.
Even though the effects of transplanting or planting time on onion growth are varied, depending on weather conditions in different growing areas, earlier transplanting commonly improved plant growth in overwintered bulb onions (Abou Khadrah et al., 2017; Devulkar et al., 2015; Han and Bae, 1976). Plastic mulching or covering is an effective way to reduce stand reduction during winter and to increase initial vegetative growth after overwintering because their effects included increased soil temperature and soil moisture content (Choi and Han, 1987; Lee, 2010; Suh and Kim, 1991; Suh et al., 1991).

Onion bulb yield. The average total bulb yield was higher during the 2015/2016 growing season $\left(70.5 \mathrm{Mg} \cdot \mathrm{ha}^{-1}\right)$ than during 2016/ 2017 (46.7 Mg.ha ${ }^{-1}$ ), but the marketable bulb yield was lower during 2015/2016 (32.0 $\mathrm{Mg} \cdot \mathrm{ha}^{-1}$ ) than during 2016/2017 (38.5 $\mathrm{Mg} \cdot \mathrm{ha}^{-1}$ ) (Table 6). This result was mainly due to the increased unmarketable bulb yield, with $33.2 \mathrm{Mg} \cdot \mathrm{ha}^{-1}$ bolters and $3.9 \mathrm{Mg} \cdot \mathrm{ha}^{-1}$ doubles in 2015/2016 compared with 3.9 $\mathrm{Mg} \cdot \mathrm{ha}^{-1}$ bolters and $0.3 \mathrm{Mg} \cdot \mathrm{ha}^{-1}$ doubles in 2016/2017. Large bulb yield was higher in $2015 / 2016$ than in $2016 / 2017$, whereas medium and small bulb yields were lower in $2015 / 2016$ than in 2016/2017. Marketable bulb yield of 'Katamaru' (38.9 Mg.ha- $\mathrm{ha}^{-1}$ was greater than that of 'Sunpower' (31.6 $\left.\mathrm{Mg} \cdot \mathrm{ha}^{-1}\right)$, whereas the bolted and doubled bulb yields of 'Katamaru' (17.1 Mg.ha' ${ }^{-1}$ ) 


\begin{tabular}{|c|c|c|c|c|c|c|c|c|c|c|c|c|c|c|c|c|}
\hline \multirow[b]{3}{*}{ Cultivar } & \multirow{3}{*}{$\begin{array}{c}\text { Transplanting } \\
\text { date }\end{array}$} & \multirow{3}{*}{$\begin{array}{l}\text { Mulch } \\
\text { type }\end{array}$} & \multicolumn{7}{|c|}{$2015 / 2016$} & \multicolumn{7}{|c|}{$2016 / 2017$} \\
\hline & & & \multicolumn{4}{|c|}{ Marketable yield $\left(\mathrm{Mg} \cdot \mathrm{ha}^{-1}\right)$} & \multicolumn{3}{|c|}{ 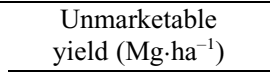 } & \multicolumn{4}{|c|}{ Marketable yield $\left(\mathrm{Mg} \cdot \mathrm{ha}^{-1}\right)$} & \multicolumn{3}{|c|}{$\begin{array}{c}\text { Unmarketable } \\
\text { yield }\left(\mathrm{Mg} \cdot \mathrm{ha}^{-1}\right)\end{array}$} \\
\hline & & & Large & Medium & Small & Total & Bolters & Doubles & Rots & Large & Medium & Small & Total & Bolters & Doubles & Rots \\
\hline \multirow{6}{*}{ Sunpower } & & Black & 20.5 & 5.1 & 0.3 & 25.9 & 47.5 & 2.3 & 1.0 & 23.1 & 28.2 & 2.7 & 54.0 & 2.8 & 0.6 & 3.1 \\
\hline & & No mulch & 1.3 & 0.5 & 0.0 & 1.9 & 49.3 & 3.1 & 0.0 & 7.7 & 27.4 & 4.2 & 39.3 & 1.0 & 0.5 & 3.8 \\
\hline & 5 Nov. & Transparent & 8.3 & 1.8 & 0.0 & 10.1 & 60.2 & 12.4 & 0.0 & 7.6 & 26.0 & 2.1 & 35.7 & 8.0 & 2.2 & 5.1 \\
\hline & & Black & 24.8 & 7.4 & 0.1 & 32.4 & 43.0 & 7.7 & 1.9 & 9.4 & 34.1 & 3.1 & 46.6 & 3.8 & 0.0 & 3.2 \\
\hline & & Black & 24.4 & 21.9 & 1.1 & 47.5 & 20.0 & 0.8 & 1.0 & 2.6 & 24.6 & 7.7 & 34.9 & 0.0 & 0.0 & 4.0 \\
\hline & & No mulch & 9.9 & 28.5 & 1.6 & 40.0 & 13.5 & 1.3 & 4.0 & 4.3 & 21.3 & 2.5 & 28.1 & 0.0 & 0.0 & 2.0 \\
\hline \multirow[t]{5}{*}{ Katamaru } & 20 Oct. & Transparent & 20.7 & 2.7 & 0.5 & 24.0 & 45.8 & 1.8 & 0.0 & 14.2 & 23.2 & 2.0 & 39.1 & 15.0 & 0.4 & 5.9 \\
\hline & & Black & 30.2 & 7.6 & 0.3 & 38.1 & 40.7 & 4.6 & 3.9 & 16.3 & 30.9 & 2.8 & 50.0 & 5.6 & 0.0 & 3.9 \\
\hline & & No mulch & 11.6 & 3.1 & 0.3 & 15.0 & 37.3 & 2.1 & 0.0 & 3.4 & 24.9 & 5.2 & 33.5 & 0.0 & 0.0 & 8.0 \\
\hline & 5 Nov. & Transparent & 50.3 & 6.9 & 0.6 & 57.9 & 32.7 & 3.1 & 2.4 & 7.2 & 22.1 & 6.2 & 33.5 & 9.1 & 0.0 & 4.1 \\
\hline & & Black & 31.8 & 8.3 & 0.5 & 40.7 & 36.1 & 2.5 & 5.1 & 4.1 & 39.1 & 5.5 & 48.8 & 2.4 & 0.3 & 2.3 \\
\hline \multicolumn{17}{|l|}{ F-test ${ }^{2}$} \\
\hline \multicolumn{3}{|c|}{ Year $(\mathrm{Y})$} & $* *$ & $* *$ & $* *$ & $* *$ & $* *$ & $* *$ & $* *$ & & & & & & & \\
\hline \multicolumn{2}{|c|}{ Cultivar (C) } & & $* *$ & NS & ** & $* *$ & $* *$ & NS & NS & & & & & & & \\
\hline \multicolumn{2}{|c|}{ Transplanting date $(\mathrm{T})$} & & NS & ** & ** & $* *$ & $* *$ & NS & NS & & & & & & & \\
\hline \multicolumn{2}{|c|}{ Mulch type (M) } & & $* *$ & $* *$ & NS & ** & $* *$ & $*$ & NS & & & & & & & \\
\hline \multicolumn{2}{|c|}{$\mathrm{Y}^{*} \mathrm{C}$} & & $* *$ & $* *$ & $* *$ & $* *$ & $* *$ & NS & NS & & & & & & & \\
\hline \multicolumn{2}{|l|}{$\mathrm{Y} * \mathrm{~T}$} & & ** & ** & ** & ** & ** & NS & $*$ & & & & & & & \\
\hline \multicolumn{2}{|l|}{$\mathrm{Y} * \mathrm{M}$} & & ** & NS & NS & $*$ & NS & NS & $*$ & & & & & & & \\
\hline \multicolumn{2}{|l|}{$\begin{array}{l}\text { C*T } \\
C * \mathrm{M}\end{array}$} & & NS & NS & $*$ & NS & NS & NS & NS & & & & & & & \\
\hline \multirow{2}{*}{\multicolumn{2}{|c|}{$\begin{array}{l}\mathrm{C}^{*} \mathrm{M} \\
\mathrm{T} * \mathrm{M}\end{array}$}} & & $*$ & NS & NS & NS & NS & NS & NS & & & & & & & \\
\hline & & & * & NS & NS & $*$ & NS & NS & NS & & & & & & & \\
\hline \multicolumn{2}{|l|}{$\mathrm{Y} * \mathrm{C} * \mathrm{~T}$} & & NS & $*$ & $*$ & NS & NS & NS & NS & & & & & & & \\
\hline \multicolumn{2}{|l|}{$\mathrm{Y}^{*} \mathrm{C} * \mathrm{M}$} & & NS & NS & NS & NS & NS & NS & $*$ & & & & & & & \\
\hline $\mathrm{Y} * \mathrm{~T} * \mathrm{M}$ & & & NS & ** & $*$ & ** & NS & $*$ & NS & & & & & & & \\
\hline
\end{tabular}

${ }^{\mathrm{z}}$ Statistics came from the 2015/2016 and 2016/2017 growing seasons.

Ns, *, **Nonsignificant or significant at $P \leq 0.05$ or 0.01 , respectively.

were lower than those of 'Sunpower' (24.3 $\left.\mathrm{Mg} \cdot \mathrm{ha}^{-1}\right)$. Marketable bulb yield increased with later transplanting time, whereas the unmarketable bulb yield was greater for onions transplanted on 20 Oct. (31.9 Mg.ha $\left.{ }^{-1}\right)$ and on 5 Nov. $\left(31.5 \mathrm{Mg} \cdot \mathrm{ha}^{-1}\right)$ than on 20 Nov. (9.5 $\left.\mathrm{Mg} \cdot \mathrm{ha}^{-1}\right)$. Onions grown with black plastic mulch had the greatest bulb yield (43.0 $\mathrm{Mg} \cdot \mathrm{ha}^{-1}$ ), followed by those grown with transparent mulch $\left(34.7 \mathrm{Mg} \cdot \mathrm{ha}^{-1}\right)$ and those grown with no mulch $\left(28.0 \mathrm{Mg} \cdot \mathrm{ha}^{-1}\right)$.

Marketable bulb yield of 'Katamaru' $\left(38.9 \mathrm{Mg} \cdot \mathrm{ha}^{-1}\right)$ was greater than that of 'Sunpower' $\left(23.7 \mathrm{Mg} \cdot \mathrm{ha}^{-1}\right.$ ) during the $2015 / 2016$ growing season; however, in 2016/2017, there was no difference in the marketable bulb yield between the two cultivars. On the contrary, the bolted bulb yield was greater for 'Sunpower' $\left(39.7 \mathrm{Mg} \cdot \mathrm{ha}^{-1}\right)$ than for 'Katamaru' $\left(15.4 \mathrm{Mg} \cdot \mathrm{ha}^{-1}\right)$ in 2015/2016, whereas there was no difference between the two cultivars in 2016/2017. In terms of the combination effects of the growing year and transplanting time, the later the transplanting times, the greater the marketable bulb yield in $2015 / 2016$. However, the marketable bulb yield of onion transplanted on 20 Nov. was significantly lower than that of those transplanted on 20 Oct. and 5 Nov. during the 2016/2017 growing season. Lower bolted bulb yield of onions transplanted on 20
Nov. (10.4 Mg.ha ${ }^{-1}$ ) compared with those transplanted on 20 Oct. $\left(46.6 \mathrm{Mg} \cdot \mathrm{ha}^{-1}\right)$ and 5 Nov. (42.7 Mg.ha ${ }^{-1}$ ) in 2015/2016 resulted in greater marketable yield. Marketable bulb yield grown with black plastic mulch was highest during the second growing season, whereas the unmarketable bulb yield was highest for onions grown with transparent plastic mulch during the second growing season. There was no difference in the large bulb yield of 'Katamaru' grown in transparent plastic mulch and black plastic mulch, whereas black plastic mulch increased the large bulb yield of 'Sunpower'. Marketable bulb yield of onions grown with black plastic mulch was not different among transplanting times, whereas transparent mulch and later transplanting dates were associated with an increased marketable yield. During the 2015/ 2016 growing season, the marketable bulb yield of onions transplanted on 20 Nov. with black or transparent plastic mulch was the greatest among treatments; however, in 2016/ 2017 , the marketable yield was the highest for onions transplanted on 20 Oct. or in November with black plastic mulch.

For overwintered bulb onions in areas with severe winters, mulching with plastic mulch during the whole season or covering plants with plastic mulch or NPP are effective methods of promoting root establishment after transplanting, reducing stand reduction due to freezing or frost injury, enhancing initial vegetative growth after overwintering, increasing the bulb yield (Choi and Han, 1987; Ha et al., 2007; Lee, 2010; Suh and Kim, 1991, 1992; Suh et al., 1991; Siwek et al., 2013; Varina and Roka, 2000). However, mulching or covering frequently increased the unmarketable bulb yield associated with bolting or doubled bulbs (Suh and Kim, 1991; Varina and Roka, 2000). Ha et al. (2007) reported that in one study of mulch types and transplanting times without the NPP covering, earlier transplanting times irrespective of mulch type increased the marketable bulb yield, whereas the yield of bolted and doubled bulbs increased for onion plants transplanted on 20 Oct. with transparent plastic mulch. Suh and Kim (1992) noted significant differences in the levels of bolting and doubled bulbs depending on the sowing dates, cultivars, and year (presumably weather-related) for short-day onions.

In conclusion, covering with NPP irrespective of the mulch type could result in a significantly increased unmarketable bulb yield for onions transplanted from late October to early November with comparatively early maturing cultivars, and especially during years with high temperatures during early 
November to early December. When the temperatures from early November to early December are similar to the temperatures during an average year, the marketable bulb yield could increase with an NPP covering, especially for onion plants grown using black plastic mulch or no mulch and transplanted during late October to early November.

\section{Literature Cited}

Abou Khadrah, S.H., A.A. El-Sayed, L.S.M. Gereies, and W.K.L. Abdelmasieh. 2017. Response of onion yield and quality to different planting date, methods and density. Egypt. J. Agron. 39:203-219.

Brewster, J.L. 1985. The influence of seedling size and carbohydrate status and of photon flux density during vernalization on inflorescence initiation in onion. Ann. Bot. (Lond.) 55:403414.

Brewster, J.L. 2008. Onions and other vegetable alliums, 2nd edition. Crop production science in horticulture series 15. CABI. p. 123-146.

Choi, S.K. and K.P. Han. 1987. The effect of mulching methods on growth and yield in onion (Allium cepa L.). Res. Rept. of Jeonnam Provincial Rural Development Administration. p. $167-172$.

Coolong, T.W. and W.M. Randle. 2003. Temperature influences flavor intensity and quality in 'Granex 33' onion. Amer. Soc. Hort. Sci. 128:176-181.

Devulkar, N.G., D.R. Bhanderi, S.J. More, and B.A. Jethava. 2015. Optimization of yield and growth in onion through spacing and time of planting. Green Farming 6:305-307.

Diaz-Perez, J.C., W.M. Randle, G.E. Boyhan, R.W. Walcott, D. Giddings, D. Bertrand, H.F. Sanders, and R.D. Gitaitis. 2004. Effects of mulch and irrigation system on sweet onion: I. Bolting, plant growth, and bulb yield and quality. J. Amer. Soc. Hort. Sci. 129:218-224.

Dragland, S. 1974. Nitrogen and water requirements in onions. Forskning og Forsok I Landbruket. 26:93-113.

Enciso, J., B. Wiedenfeld, J. Jifon, and S. Nelson. 2009. Onion yield and quality response to two irrigation scheduling strategies. Scientia Hort. 120:301-305.

Food and Agriculture Organization (FAO). 2016. FAOSTAT. 26 June 2018. <http://faostat.fao. org $>$.

Ha, I., W. Song, J. Lee, and M. Cheon. 2007. Technical approach for onion cultivation under environmental-friendly agriculture. 4 . Determination of transplanting date and selection of natural covering materials for EnvironmentalFriendly Agriculture. Rept. of cooperative Res. of Rural Development Administration. p. 63-82.
Han, K.P. and S.T. Bae. 1976. Determination of transplanting time for bulb onion. Res. Rept. of Jeonnam Provincial Rural Development Adiministration. p. 349-355.

Ito, K. 1956. Studies on the bolting of onion. I. Relation between the flower bud formation and the bulb division. J. Jpn. Soc. Hort. Sci. 25:187-193.

Jung, H., Y. Choi, J. Oh, and G. Lim. 2002. Recent trends in temperature and precipitation over South Korea. Intl. J. Climatol. 22:1327-1337.

Kalbarcyk, R. 2010. The Application of the cluster analysis in recognizing weather patterns conducive to large and small crops of mid-late onion cultivars (Allium Cepa L.) in Poland. Not. Bot. Hort. Agrobot. Cluj. 38:100-108.

Kato, T. 1963. Physiological studies on bulbing and dormancy of onion plant. III. Effects of external factors on the bulb formation and development. Japan. Soc. Hort. Sci. 33:53-61.

Kato, T., K. Yamata, T. Haioka, S. Kawajaki, and A. Shoma. 1999. Vegetable encyclopedia 11. Onion, asparagus and Japanese angelica tree. 4th edition. Rural Cultivation Association, Japan.

Korea Meteorological Administration (KMA). 2018. 26 June 2018. <www.weather.go.kr/ weather/climate/data_sfc_ann_mon.jsp>.

Lee, J. 2010. Effect of application methods of organic fertilizer on growth, soil chemical properties and microbial densities in organic bulb onion production. Scientia Hort. 124:299305.

Lee, J. 2015. Onion: From life cycle to organic and no-till production. Dulyouk Publishing Co., Republic of Korea. p. 259-264.

Lee, J., B. Min, S. Hwang, H. Kim, I. Ha, J. Moon, J. Suh, Y. Kwon, M. Lee, S. Kim, and J. Jeong. 2017. Onion diseases, pests and physiological disorder strategies against climate change. 1st edition. Jinju Wonjin Publishing, Republic of Korea. p. 41-43.

Magruder, R. and H.A. Allard. 1937. Bulb formation in some American and European varieties of onions as affected by length of day. J. Agr. Res. 54:719-752.

Min, S.K., S.W. Son, K.H. Seo, J.S. Kug, S.I. An, Y.S. Choi, J.H. Jeong, B.M. Kim, J.W. Kim, Y.H. Kim, J.Y. Lee, and M.I. Lee. 2015. Changes in weather and climate extremes over Korea and possible causes: A review. Asia-Pac. J. Atmos. Sci. 51:103-121.

Potopova, V., P. Zahradnicek, P. Stepanek, L. Turkott, A. Farda, and J. Soukup. 2016. The impacts of key adverse weather events on the field-grown vegetable yield variability in the Czech Republic from 1961 to 2014. Intl. J. Climatol. 37:1648-1664.

Rural Development Administration (RDA). 2010. The standard of fertilizer application on crop species. National Institute of Agricultural Science, RDA, Republic of Korea. p. 100-101.

Schwartz, H.F. and S.K. Mohan. 2008. Compendium of onion and garlic diseases and pests. 2nd ed. APS Press, The American Phytopathological Society, USA. p. 8-10.

Shishido, Y. and T. Saito. 1975. Studies on the flower bud formation in onion plants. I. Effects of temperature, photoperiod and light intensity on the low temperature induction of flower buds. J. Jpn. Soc. Hort. Sci. 44:122130.

Shishido, Y. and T. Saito. 1976. Studies on the flower bud formation in onion plants. II. Effects of physiological conditions on the low temperature induction of flower buds. J. Jpn. Soc. Hort. Sci. 45:160-167.

Shock, C.C., E.B.G. Feibert, and L.D. Saunders. 1998. Onion yield and quality affected by soil water potential as irrigation threshold. HortScience 33:1188-1191.

Shock, C.C. and F.-X. Wang. 2011. Soil water tension, a powerful measurement for productivity and stewardship. HortScience 46:178185.

Siwek, P., A. Libik, and I. Zawiska. 2013. The impact of biodegradable nonwoven fabric covers on the yield and quality of overwintering onions. Acta Sci. Pol. Hortorum Cultus 12:3-11.

Statistics Korea. 2018. Cultivated area of garlic and onions in 2018. No. 267. 23 July 2018. $<$ http://kostat.go.kr/portal/eng/pressReleases/ 2/1/index.board $>$.

Suh, J.K. and Y.B. Kim. 1991. Study on improvement of mulching culture method in onion (Allium cepa L.): 1. Influence of mulch materials and times on growth and yield. Res. Rept. Rural Development Adiministration (Hort.) 33:31-36.

Suh, J.K. and Y.B. Kim. 1992. Study on improvement of mulching culture method in onion (Allium cepa L.): 1. Influence of sowing date on growth and yield in early cultivars. Res. Rept. Rural Development Administration (Hort.) 33:31-36.

Suh, J.K., Y.B. Kim, K.S. Lee, and K.Y. Han. 1991. Study on improvement of mulching culture method in onion (Allium cepa L.): 1 . Influence of polyethylene film covering and drawing out date on growth and yield. Res. Rept. Rural Development Administration (Hort.) 33:21-28.

Van Eeden, F.J. and J.M. Myburgh. 1971. Irrigation trials with onions. Agroplantae 3:57-62

Varina, C.S. and F.M. Roka. 2000. Comparison of plastic mulch and bare-ground production and economics for short-day onions in a semitropical environment. HortTechnology 10:326330 . 